\title{
Marine natural products: the new generation of pharmacotherapeutics
}

\author{
Rajeev Goel $^{1 *}$, Binny Mahendru², Tushar Saini ${ }^{3}$
}

\begin{abstract}
${ }^{1}$ Department of Biophysics, Dr. Rajendra Prasad Government Medical College, Kangra, Himachal Pradesh, India ${ }^{2}$ Department of Pharmacology, Dr. Radhakrishnan Government Medical College, Hamirpur, Himachal Pradesh, India ${ }^{3}$ Department of Forensic Medicine, Dr. Rajendra Prasad Government Medical College, Kangra, Himachal Pradesh, India
\end{abstract}

Received: 29 April 2021

Revised: 01 June 2021

Accepted: 02 June 2021

\section{*Correspondence: \\ Dr. Rajeev Goel, \\ Email:rgoel302@yahoo.com}

Copyright: $(\odot$ the author(s), publisher and licensee Medip Academy. This is an open-access article distributed under the terms of the Creative Commons Attribution Non-Commercial License, which permits unrestricted non-commercial use, distribution, and reproduction in any medium, provided the original work is properly cited.

\begin{abstract}
The biomedical potential of the sea has gone largely unexplored so far, despite the fact that it covers three quarters of the planet surface and the fact that life on Earth originated from the sea. However, with the arrival of the professional deep sea divers, the marine researchers have gained access to all sorts of marine creatures like sponges, corals, sea urchins, sea squirts, hydroids, sea anemones, fishes and mollusks as well as to varied types of sea plants including algae and the other micro-organisms embedded in the sea bed. The biomedical scientists are exploiting these all to extract marine natural products (MNPs) having pharmacological properties that may one day cure long list of illnesses varying from bacterial infections to cancer, Alzheimer's and AIDS and is the focus of this review article.
\end{abstract}

Keywords: Marine organisms, Marine natural products, Therapeutics and human diseases

\section{INTRODUCTION}

Scientists so far have been purely dependent on the tropical forests and terrestrial ecosystem for unusual substances having medicinal properties which have been in use either as direct extracts or synthetic redesigns of the plant molecules. Anti-malarial drug quinine from the bark of cinchona tree, aspirin from the willow bark, morphine from opium poppies and taxol to treat cancer from the yew tree of rain forests are a few such examples. The quest to find novel sources of medicines to fight developing antibiotic resistance and the diseases of the industrialized world has forced researchers to explore marine animals and plants also.

The recent researches on marine biota have proved that it, in fact, is a great store house of useful bio-chemicals and lifesaving medicines which otherwise are not found in terrestrial natural products. ${ }^{1}$ Marine organisms need these bioactive compounds for purposes such as reproduction, communication and for their own protection against predation, infection and competition. ${ }^{2}$ The biologically active chemical diversity from the vast plethora of marine organisms is now under translation into novel biomedicines having therapeutic potential.

\section{Marine natural products from the incredible sponges}

The marine sponges are the simplest of multi-cellular organisms and are collections of loosely organized single cells with no apparent true organs or tissues. The scientific term for sea sponges is Porifera which literally means pore bearing. Sponges being static organisms produce deadly toxins, to protect themselves from their predators, that are known to have medicinal properties beneficial to humans.

The sponges are thought to be a goldmine containing many bioactive molecules that can fight cancer and inflammation without minimal side effects which are associated with the nowadays available anti-cancerous and anti-inflammatory 
drugs. Several sponge species produce compounds that show great promise as drugs to combat malaria, tuberculosis, carcinomas and other infectious diseases.
Consequently, sponges are finding a niche in medical research. ${ }^{3}$ Many compounds isolated from different types of sea sponges are now in human clinical trials against cancer and other diseases. ${ }^{4}$

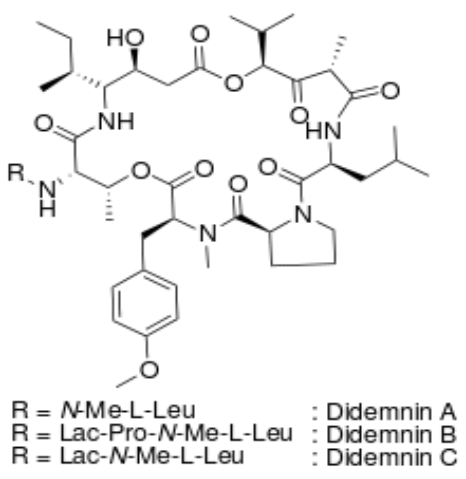

Didemnins

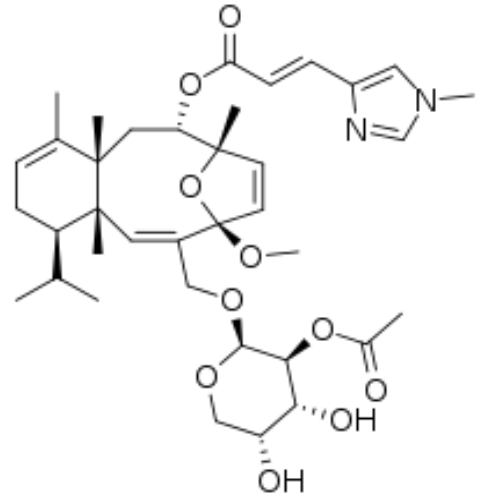

Eleutherobin

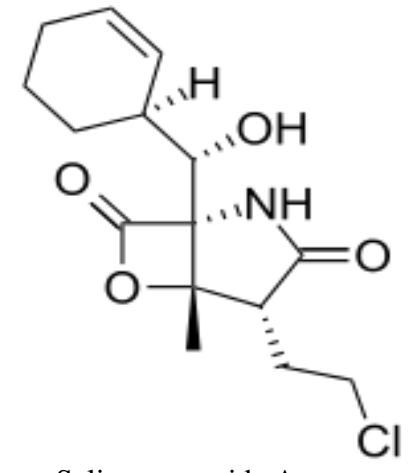

Salinosporamide A<smiles>C=C/C=C\[C@H](C)[C@H](OC(N)=O)[C@@H](C)[C@H](O)[C@@H](C)C/C(C)=C\[C@@H](C)[C@@H](O)[C@@H](C)/C=C\[C@H](O)C[C@H]1OC(=O)[C@H](C)[C@H](O)[C@H]1C</smiles>

Discodermolide

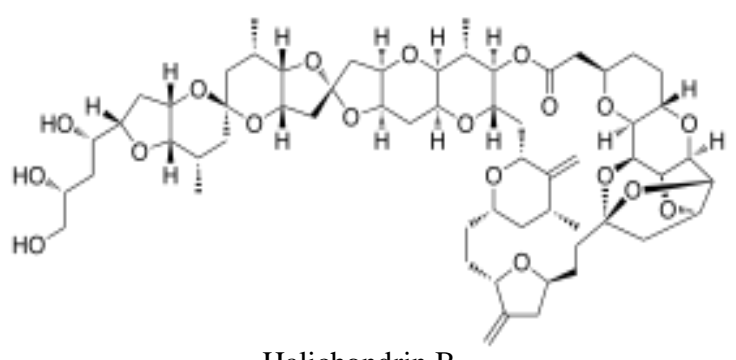

Halichondrin B

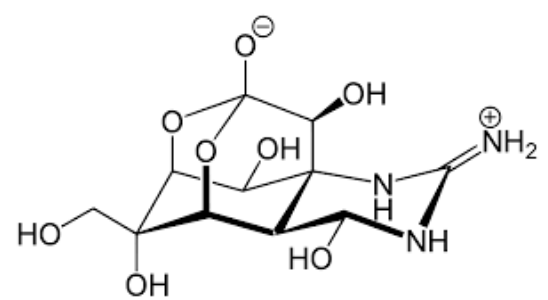

Tetrodotoxin

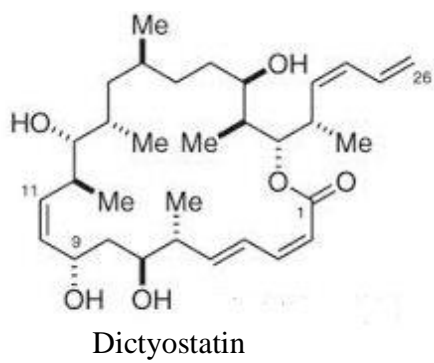

Dictyostatin

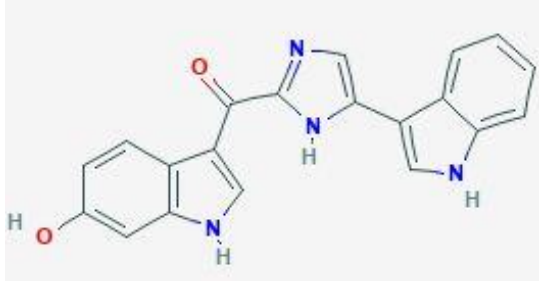

Topsentin

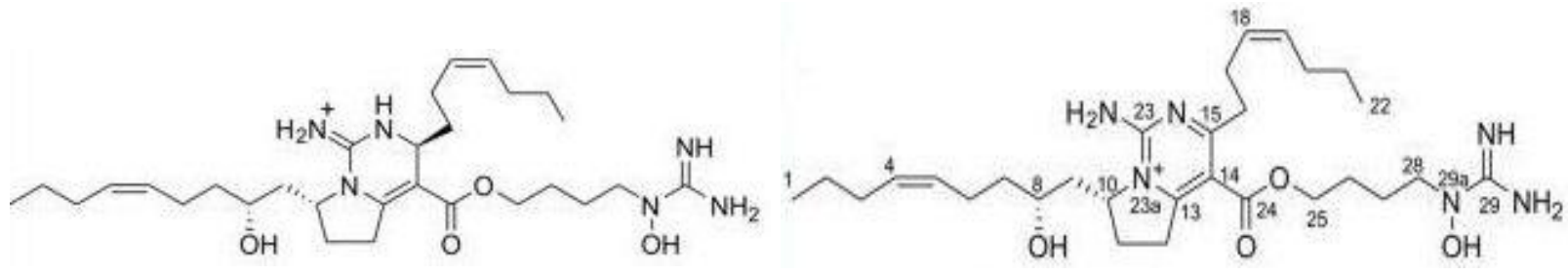

Urupocidin A

Urupocidin C

Figure 1: Chemical structures of marine natural products having promising therapeutic applications. 


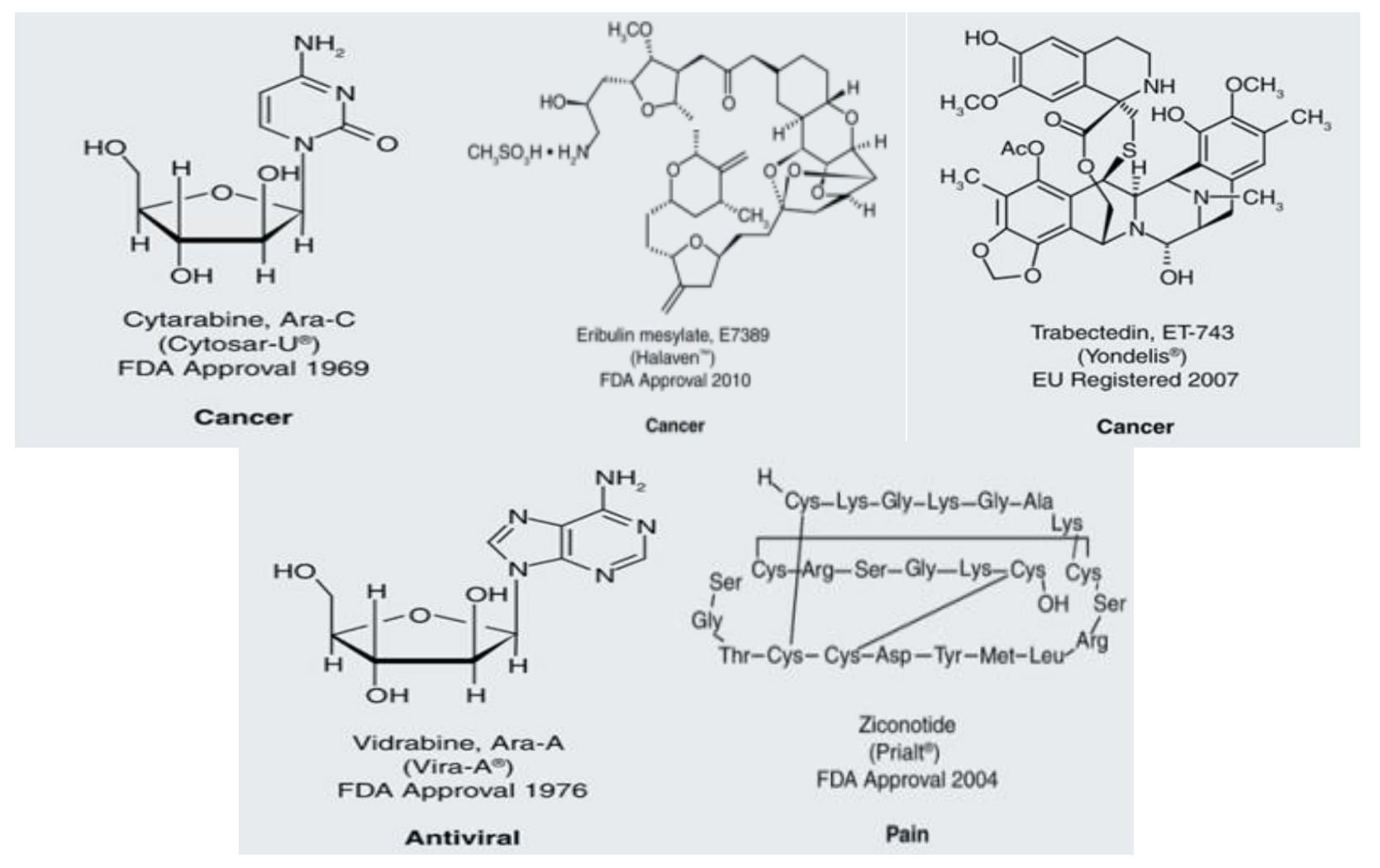

Figure 2: Marine drugs on the market and their therapeutic uses.

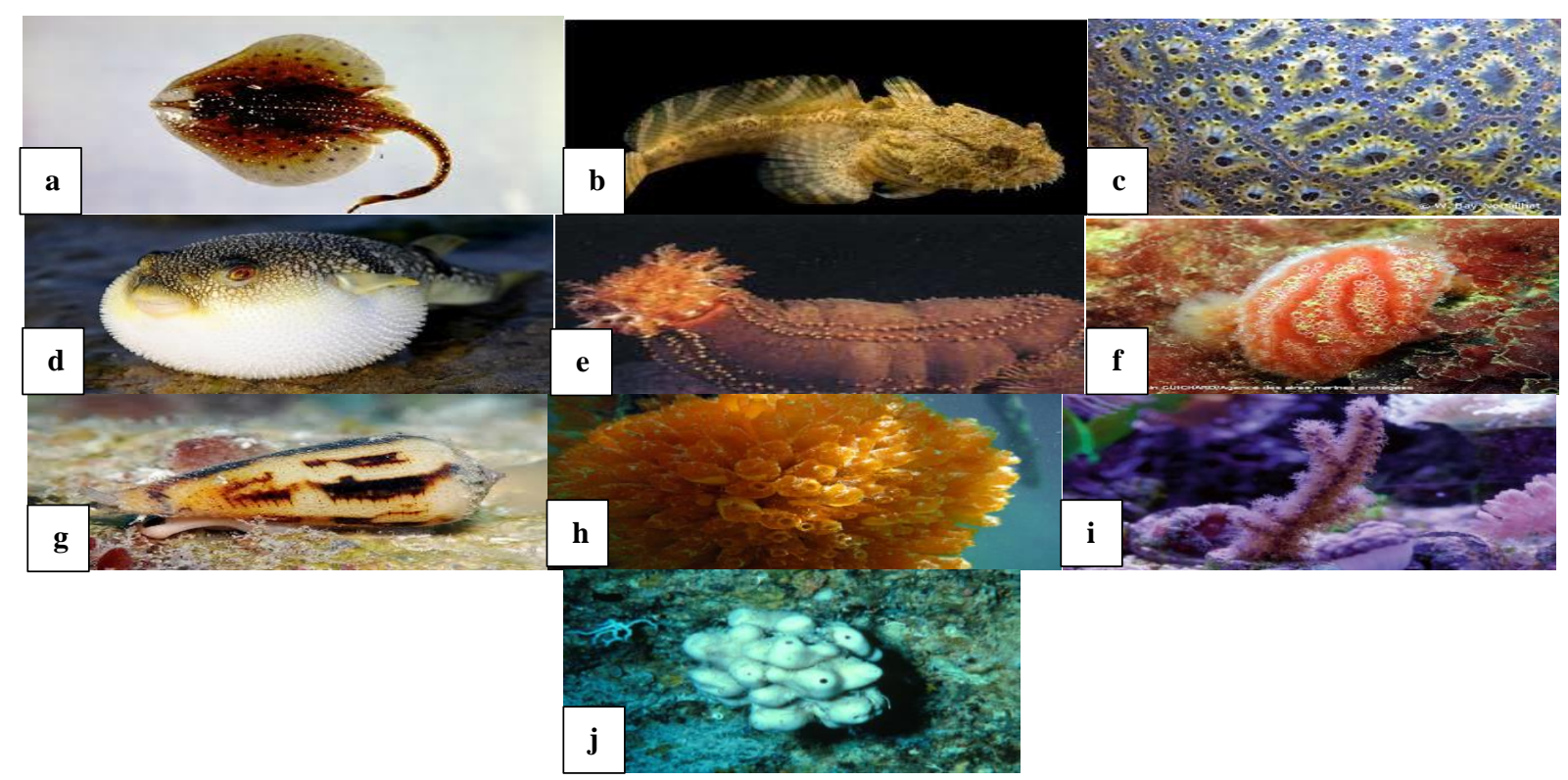

Figure3: Some marine vertebrates and invertebrates of therapeutic importance: (a) Leucoraja erinacea (little skate

fish); (b) Opsanus Tau (toad fish); (c) Botryllus schlosseri (star tunicate); (d) Tetraodontidae (pufferfish); (e)

Cucumaria frondose (sea cucumber); (f) Aplidium albicans (tunicate); (g) Conus magus (sea snail); (h) Ecteinascidin turbinate (sea squirt); (i) Pseudopterogorgia (sea fan): (j) Discodermia dissolute (sea sponge).

\section{Halichondrin B}

A compound halichondrin $\mathrm{B}$ belonging to a chemical family known as macrolides isolated from the Japanese sponge, Halicondria okadai, shows antitumor activity in melanoma, leukemia, breast and esophagus cell lines (Figure 1). It binds tubulin and alters the tubulin depolymerisation in the cells. ${ }^{5}$ A halichondrin $\mathrm{B}$ analog, 
eribulin mesylate also known as E7389-a synthetic compound developed by a Massachusetts based Eisai pharmaceutical is currently in the first phase of clinical trial for treatment of non-small cell lung cancer (Figure 2). ${ }^{6}$ Eribulin mesylate (Halaven $\left.{ }^{\circledR}\right)$ has been approved for treatment of metastatic breast cancer. ${ }^{7}$ It exhibits therapeutic effect by binding to the plus ends of the microtubules and stops their growth with no effect on microtubule shortening by forming non- productive tubulin aggregates. $^{8}$

\section{Discodermolide}

Discodermolide, a poly hydroxylated lactone is a promising natural product discovered to date to have an anti-cancerous properties against the solid tumors (Figure 1). ${ }^{9}$ It has been isolated from the deep sea sponge, Discodermia dissolute (Figure 3). Discodermolide exhibits better water solubility, facilitating patient delivery. It stabilizes microtubules in the cells and is believed to be more potent than Taxol®, a widely used anti-cancer drug extracted from the bark of Pacific yew tree. It also exhibits activity against the multi drugs and Taxol ${ }^{\circledR}$ resistant tumors. Discodermolide has been licensed for further development and the compound has completed phase I clinical trials. ${ }^{10}$

\section{Topsentin}

The compound topsentin (Fig.1) from the deep water sponge, Spongosporites ruetzleri (from the family Halichondriidae, genus sponogosorites) displays great promise as an anti-inflammatory agent to treat arthritis and skin irritations. ${ }^{11}$ Topsentin is a novel indole alkaloid also having anti-tumor and anti-viral properties and is under investigation for the treatment of colon cancer and even alzheimer's disease. The compound is currently under preclinical development stage. ${ }^{11}$

\section{Dictyostatin}

Dictyostatin-1 ( Fig.1) originally isolated from a shallow water sponge in the Spongia genus, which is found off the cost of Republic of Maldives, is an anticancer compound in preclinical development. The compound appears to be a great promise in lab and more potent than Taxol® in action. $^{12}$

\section{Nucleosides}

The nucleosides, spongo-thymidine and spongo-uridine isolated from the Caribbean sponge Tectitethya crypta (family Tethylidae) contain an unusual and rare sugararabinose instead of the ribose, a ubiquitous sugar in nucleosides which forms the building blocks of nucleic acids. It was rather the discovery of these novel nucleosides spongo-thymidine and spongo-uridine, which ushered the era of marine derived drugs in 1950s. ${ }^{13}$ These nucleosides were discovered to possess the antiviral properties via inhibition of reverse transcriptase activity. The analogues such as Ara-A (3, Vidarabine $\left.{ }^{\circledR}\right)$ and Ara-C (4, Cytrabine) with improved anti-viral activities have been synthesized on the basis of these marine nucleosides (Figure 2). ${ }^{13}$ The isolation of $\mathrm{C}$-nucleosides from the Caribbean sponge, Cryptotethya crypta, provided the basis for the synthesis of cytrabine (Cytosar®), a FDA approved drug in 1969 to be used in patients with leukemia and lymphoma particularly. ${ }^{14}$

\section{Other compounds}

A black sponge from Plakinastrella species, collected by U. S. marine scientists from the west of the Felicite Island in the Indian Ocean possesses potent anti-fungal activity. This black sponge produces cyclic peroxy acids which inhibit growth of Candida albicans comparable to amphotericin B, the anti-fungal gold standard. ${ }^{15}$

Many compounds from the sponges induce apoptosis and act as anti-cancer agents. Renieramycin isolated from the sponge genera Reniera induces apoptosis in lung cancer cells. A lectin from the sponge Cinachyrella apion also causes cell death in tumor cells. ${ }^{16}$

The marine biotech company by the name porifarma is farming two sponge species Dysidea avara and Chondrosia reniformis. The former produces a compound avarol, a cyto-statically active compound shown to have antitumor, antibacterial and anti-fungal properties and the latter is a good source of collagen that can be converted into nano-particles to be used for drug delivery to the target locations. ${ }^{17}$

\section{Bioactive compounds from novel marine microbes}

The discovery of the group of marine microbes from the coral reef sponges and from the marine sediments has provided an opportunity to microbiologists to look for novel antibiotics. The studies have revealed an elevated microbial population that is exceptionally bioactive in many sponges. Marine invertebrates such as corals and sponges are hosts to a multitude of microorganisms. The nature of relationship between the microbes and the host organisms is not yet fully understood. The presence of micro-organisms in the marine invertebrates seems to play a role in keeping them healthy and nourished besides producing defense chemicals to protect them from their predators. $^{18}$

Microorganisms such as bacteria, cyanobacteria and fungi contribute to as much as $50 \%$ to $60 \%$ of sponges' biomass. The $50 \%$ of the cellular volume of the Australian tropical sponge, Dysidea herbacea, for example is composed of the Cyanobacterium, Oscillatoria spongeliae. ${ }^{19}$ The bacterial population in sponges could be very diverse and efforts are on to culture them in the lab to procure new antibiotics. It is believed that some of the bioactive molecules are likely to come from these bacteria rather than the sponges themselves. For example, an extract from a common Chesapeake Bay sponge, Microciona porlifera, contains 
around 150 bacterial isolates which inhibit the growth of H37Rv strain of Mycobacterium tuberculosis responsible for tuberculosis, a leading cause of death after HIV/AIDS. ${ }^{20}$

The ocean floor itself is a next major potential source of bioactive compounds. It is estimated that there are one billion living cells per cubic centimeters of seafloor sediment. The micro-organisms diversity in the deep ocean is boundless. These microbes can be used more quickly, efficiently, cost effectively and sustainably as compared to other marine organisms and can be harvested with little impact on the natural environment, in case they can be cultured in large quantities in lab.

It is worth noticing that $70 \%$ of the naturally occurring antibiotics such as actinomycin, streptomycin, novobiocin are produced by soil based actinomycetes family. However, the discovery of many novel marine actinomycetes from the marine environment such as sea floor sediments, algae and sponges may lead to the availability of novel antibiotics which may overcome the menace of antibiotic resistance in future. ${ }^{21}$

Actinomycetes are responsible for the production of about half of the discovered bioactive secondary metabolites mainly antibiotics, antitumor agents, immunosuppressive agents and enzymes. Many new chemical compounds from the marine actinomycetes now stands isolated and ten new genera of microbes have been remarkably characterized including the genus Salinispora from which 2,500 new strains have been discovered. ${ }^{22}$

Marine bacteria Salinispora tropica isolated from the marine sediments produce a compound salinosporamide-A (NPI-0052, Fig. 1), a novel $\beta$-lactone- $\gamma$-lactam, that exhibits cytotoxicity against breast cancer, colon cancer, non-small cell lung cancer and melanoma (Figure 1). ${ }^{23}$ NPI-0052 is an orally active proteosome inhibitor that induces apoptosis in multiple myeloma cells with mechanisms distinct from the commercial proteosome inhibitor anticancer drug bortezomib. ${ }^{23}$

A novel metabolite diazepinomicin (ECO-4601), a unique farnesylated dibenzodiazepinone produced by marine actinomycetes (Micromonospora species) possesses antibacterial, anti-inflammatory and antitumor activities. ${ }^{24}$ It has broad spectrum of in vitro cytotoxicity and has demonstrated in vivo, activity against glioma, breast and prostate cancer in mouse models. ${ }^{24}$

Several bacterial and fungal isolates from the seawater sample were similarly assayed for the antibiotic potential. One of these isolates, the marine derived fungi Cephalosporium acremonium contains significant inhibitory activity against a number of bacterial strains. The finding rather marked the discovery of the first of the cephalosporin family of antibiotics, an important addition to fight against the range of bacterial infections. ${ }^{25}$

\section{Marine natural products from the exotic corals}

Corals, the beautiful red, pink or white creatures found in different shapes, sizes and texture which were earlier familiar only for their exotic structures are now known for new medicines. Corals are the group of marine invertebrate animals that deposit a mineral skeleton as they grow eventually producing coral reefs. The coral reefs contain a diverse assemblage of invertebrates such as corals, tunicates, mollusks, bryozoans, sponges and echinoderms that are absent from terrestrial ecosystems. Coral reefs are also home to sessile plants and fungi similar to those found on land.

A Mediterranean soft coral Sarcodictyon roseum produces a bioactive compound sarcodictyin and a similar compound named eleutherobin from a shallow water Eleutherobia species in Western Australia (Figure 1). It possesses paclitaxel (Taxol @) like anti cancerous activity and is in pre-clinical developmental stages. ${ }^{26}$

Certain corals particularly the tropical ones belonging to genera Porites, Alveopora, Acropora and Goniopora have the structure almost identical to human bone, outer hard sheath and a spongy inner core with correct pore diameter and ability to connect properly with the bone. As a result tropical coral bone substitutes are nowadays used as bone grafts to heal fractures in orthopedic, dental, craniofacial trauma and neurosurgeries. ${ }^{27}$

The natural coral structure has been successfully used to synthesize bone analogs. Coral is not implanted in its natural state although the structure and mineral composition of coral is very similar to that of bone. Following its harvest, coral is treated chemically under heat and high pressure to convert the calcium carbonate matrix to hydroxyapatite (calcium phosphate hydroxide), the normal mineral portion of the bone. It is the threedimensional structure, porosity, pore interconnections and composition of commonly used corals that confer its osteoconductive capacity. It consequently allows cell attachment and growth through the scaffold of the material, characteristic of a good support of cells. ${ }^{28}$ The initial invasion of coral by blood and bone marrow cells with subsequent vascularization is a determinant factor for bone regeneration. The coral is only osteo-conductive and is not an osteo-inductive material. ${ }^{29}$

Bamboo corals from the family Isididae (genera Keratoisis and Isidella) found at a depth of more than 1000 meters in the sea have a unique protein-based material called gorgonin that closely resembles human collagen, an important component of the bone and keratin. Gorgonin may one day substitute collagen which at present is mainly derived from cattle tissues to be used in many biomedical applications such as controlled release of medicines into the body, scaffolding for tissue engineering and other biomaterial applications. ${ }^{30}$ The risk of transmission of diseases from the cattle tissue to human makes bamboo corals a safer alternative. There are attempts to cultivate 
bamboo corals in the lab by using biotechnological approaches for the development of natural bone implants and analogs. ${ }^{30}$

A gorgonian coral feathery sea fan, Pseudopterogorgia elisabethae, found in Caribbean sea contains a compound pseudopterosin a diterpene glycoside, that relieves swelling caused by arthritis, sunburn or chemical irritants and is believed to be more active than hydrocortisone and is commercially found in the skin creams as topical antiinflammatory agent (Figure 3 ). ${ }^{31}$

\section{Novel compounds from other marine creatures}

Many other marine creatures are also under laboratory investigations to look for biochemical storehouse. A standardized liquid extract derived from shark cartilage is a promising marine based anti-angiogenic agent, neovastat (AE-941) ${ }^{32}$ It is the anti-angiogenic aspects of AE-941 that makes it extraordinary, though the substance exhibits multiple mechanisms of action. AE-941 essentially thwarts the demands of tumors for new capillaries, thereby, depriving them of oxygen and nutrition required for their growth. AE-941 is now in international phase three clinical trials for renal cell carcinomas and non-small cell lung cancer. ${ }^{33}$ Another anti-angiogenic agent is the compound squalamine, an aminosterol obtained from the spiny dogfish Squalus acanthias, a commom New England coastal shark. ${ }^{32}$

A compound called ecteinascidin (Ecteinascidin-743 or ET-743, trade name Yondelis () ) isolated from the sea squirt, Ecteinascidin turbinate (Fig.3), from the reefs in West Indies is a tetrahydro isoquinoline alkaloid and has anti-cancerous properties many times more than taxol (Figure 3). ${ }^{34}$ ET-743 is presently used to treat liposarcoma and leiomyosarcoma (Figure 2). ${ }^{35}$ Ecteinascidin uniqueness lies in preventing tumors from becoming drug resistant. $^{34}$ ET-743 is known to act by preventing the formation of a P-glycoprotein, a membrane protein, that transports chemotherapy agents out of the cancer cells thereby causing drug resistance. ET-743 is effective as inhibitor of DNA synthesis, capable of arresting the cell cycle and inducing p-53 independent apoptosis in target cells. ${ }^{36}$ The compound also exhibits tublin interactive bioactivity. Similarly, an anti-neoplastic drug PM605, developed by PharmaMar, by extracting bio-actives from an Indian Ocean tunicate is under preclinical trials. ${ }^{37}$

The coral reefs off the Philippines host a cone snail whose venom is observed as a potent pain killer, many times more potent than morphine and find its use in patients with chronic pain. The compound, ziconotide, a synthetic form of peptide extracted from the venom of a predatory tropical cone snail Conus magus, has been approved by the U. S. food and drug administration (FDA) as a pain killer to be used in terminally ill patients and is marketed as Prialt ${ }^{\circledR}$ (Figure 2 and 3). ${ }^{38}$ Prialt (ziconotide) is a 25 amino acid peptide which acts by binding to and inhibiting presynaptic calcium channels, thereby preventing neurotransmitter release. This consequently blocks nerve impulses in the key region of the spinal cord. ${ }^{39}$ The precisely targeted mode of action of ziconotide gives it an important advantage over presently available opioid drugs having side effects such as sedation and suppressed respiration. ${ }^{39}$ A protein aequorin from jelly fish Rhopilema esculentum is neuro- protective and thought to be effective in treating various neuro-degenerative disease. ${ }^{40}$

Many compounds such as didemnin and aplidine showing anti-cancerous properties have been derived from the marine ascidians or sea squirts (Subphylum tunicata) (Figure 1). Didemnim is a cyclic depsipeptide compound and is found in Caribbean tunicates of the Didemnidae family. ${ }^{41}$ It is of special significance as it has a variety of biological effects including potent antiviral and antitumor activities. Its mechanism of action has been attributed to the inhibition of DNA synthesis. ${ }^{41}$ Aplidine isolated from the tunicate Aplidium albicans is also a novel depsipeptide and is found to be cytotoxic for molt-4 leukemic cells at nanomolar concentration (Figure 3). ${ }^{42}$

An enzyme, chitosanase which fights fungal infections has been isolated from shells of shrimps, crabs and lobsters. ${ }^{43}$ An extract named paolin I from clams, oysters and abalone has antibacterial properties including against the streptococcal infections. ${ }^{44}$ A related agent paolin II has anti-cancerous and anti-viral properties particularly against herpes virus. ${ }^{45}$

Chitin, a substance found in shells of crabs and shrimps makes bonding with the red blood cells to form an artificial clot at the site of bleeding thereby sealing massive bleeding in 30 seconds. As a result, shrimp based bandages are now used by certain troops in the battlefield to stop excessive bleeding which is the main cause of death among soldiers in the field. ${ }^{46}$

A common marine invertebrate named sea cucumber, Cucumaria frondosa (family Holothuroidea), found in Philippine coastal waters contains a lectin (lectins are proteins that bind specifically to sugars in the cell membrane), which stops the growing human cancer cells in vitro (Figure 3). ${ }^{47}$

Many marine guanidinium toxins having high medical research value have also been isolated. These are tetrodotoxin (TTX) from Tetraodontidae (pufferfish), saxitoxin (STX) and its analog neosaxitoxin (NSTX) from shell fish and algae (Figure 1 and 3 ). ${ }^{48}$ TTX is a selective sodium channel blocker non-protein toxin isolated from floral egg crab Atergatis floridus; blue-ringed octopus Octopus maculosus; starfish Astropecten polyacanthus and several other shellfish species. TTX-producing bacteria were also reported to have been isolated from marine or freshwater sediments. The consumption of an organism containing TTX can cause neurological and gastrointestinal symptoms. TTX is commonly used in many laboratories as a pharmacological agent because of its ability to selectively block the sodium channels on the 
nerve membrane. ${ }^{49}$ TTX can play an alternative role against opioid and can be used as painkiller in coming years as an alternative to opioid for pain management. ${ }^{49,50}$

The guanidine group as such is of immense interest in pharmaceutical chemistry and has become a key element in many clinical drugs such as anti-diabetic drug dimethyldiguanide and the peptic ulcer drug cimetidine ${ }^{51,52}$ The diversity and complexity of cyclic and linear guanidine marine natural products from sponges, mollusks and ascidians were recently observed as polyketide synthases (PKS) and nonribosomal peptide synthetases (NRPSs) derivatives, terpene and peptide conjugates. ${ }^{53}$

Nonribosomal peptide synthetases synthesize nonribosomal peptides (NRP) which possess exceedingly broad range of biological activities, pharmacological properties and biotechnological applications. These are often siderophores (iron chelating compounds), pigments, toxins, cytostatics, antibiotics and immune-suppressants. ${ }^{53}$

Marine bacteria, cyanobacteria and fungi have emerged as a source of these non-ribosomal peptides which initially were isolated from soil microorganisms such as actinomycetes, bacilli and eukaryotic filamentous microorganisms. Non-ribosomal peptides are also found in marine invertebrates such as soft bodied gastropod mollusks called as nudibranchs but are believed to be formed by bacteria inside these organisms. ${ }^{54}$

The guanidine alkaloids isolated from the marine sponges of the Monanchora genus belonging to family Crambeidae possess wide range of biological activities such as cytotoxic, antimicrobial, antimalarial and anti-HIV properties. $^{55}$ For example, the guanidine alkaloid urupocidin A (Ur-A) has cytotoxic activity against different human cancer cell lines (Figure 1). ${ }^{56} \mathrm{Ur}-\mathrm{A}$ inhibits an EGF-induced neoplastic transformation of epithelial cells. It induces a G2/M-phase cell cycle arrest and apoptosis of human cervical carcinoma HeLa cells. ${ }^{57} \mathrm{~A}$ new bicyclic guanidine alkaloid, urupocidin $\mathrm{C}$ (Ur-C), along with the earlier known Ur-A, isolated from the rare deep-sea marine sponge Monanchora pulchra found in North-western Pacific waters exhibit acute selectivity for human prostate cancer cells and are believed to be a novel promising candidates as effective drugs against aggressive and drug resistant cancer of the prostate (Figure 1)..$^{58}$

Neutrophils play an important role in acute inflammatory responses and recent studies have expanded their role to modulate chronic inflammatory and autoimmune diseases. Several types of chemical drugs are in use to treat inflammatory disorders, but with adverse side effects. Marine natural products that inhibit neutrophil activation could therefore be used as alternative to these drugs for the treatment of inflammatory diseases. The biological and chemical diversity of marine habitats constitutes a sizeable reservoir of novel anti-inflammatory compounds such as sesquiterpenoids, diterpenes, steroids, polysaccharides, alkaloids, fatty acids and proteins isolated from diverse marine organism. ${ }^{59}$

The powdered shrimp shells are used in England as a treatment for allergies and hay fever. A product enzycol, developed from the enzymes in king crab shells helps in healing severe burns. ${ }^{60}$ Certain compounds from crab wastes are used in cleansing lotions for burns, chilblains, gangrene and varicose sores. Studies have unveiled that sea urchin pigment is rich in antioxidants, anti-inflammatory and anti-bacterial activities and can be effective in the treatment of certain eye and heart ailments. ${ }^{61}$ Anticancerous substances from the anterior and posterior salivary glands extract of octopuses like Octopus aegina have been isolated. This octopus is used traditionally by the residents of the coastal areas to cure stomach ache, diarrhoea, scabies, toothache, measles and high blood pressure. $^{62}$

\section{Marine organisms as model for human system}

The different studies are in progress for gaining biomedical knowledge to understand how the marine creatures are living in extreme environmental conditions like high pressure under the sea, total darkness, acidic, salty or alkaline conditions and low temperature that otherwise would kill human beings. This will be of immense help to apply it to human system to understand and cure diseases. For example, the little skate fish, Leucoraja erinacea, can detect light in the darkest conditions using only rods, the light sensitive cells present in retina (Figure 3). It is believed that skates because of its ability to see in the darkest conditions can be a useful model for studying the human retina and may one day help in finding cure for retinitis pigmentosa, a disease that leads to total blindness in humans. ${ }^{63}$

Toadfish having the toad like appearance has the unusual ability to regenerate its central nervous system unlike humans and the cues to regeneration in toadfish would be of importance in human neurodegenerative diseases. ${ }^{64}$ The members of entire family of ray finned fish (order Batrachoididae) are usually called toadfish or frogfish (Figure 3). The toadfish also has the fastest twitching muscles (swim bladder muscle) in the vertebrate world. It is therefore supposed to be a good model for cardiomyopathy wherein the heart muscles lose their ability to relax normally and cannot pump blood properly. ${ }^{65}$ The lab studies have shown that a myoplasmic protein called parvalbumin from common Atlantic oyster toadfish, Opsanus tau, when inserted in the muscles of the human heart helps to relax the cardiac muscle and may, therefore, find its use in patients suffering from cardiomyopathy. Paravalbumin is a $\mathrm{Ca}^{++}$binding protein of low molecular weight. $^{66}$

It is amazing to know that a starascidian or golden star tunicate Botryllus schlosseri found in the bays of Florida can re-grow or regenerate its entire body, the digestive system, heart and other tissues from its vasculature alone 
likely by using stem cells (Figure 3). The researchers are studying the self-regenerating mechanisms operating in this star tunicate to apply it to humans, which will provide insights about the potential of cells and tissues to be reprogrammed and regenerate compromised human organs. ${ }^{67}$

The studies are in progress on the molecules responsible for regulating egg and sperm interaction in sea urchin, Echinus esculentus and solitary sea squirt, Ascidia mentula (which have both types of reproductive organs) to unlock the mysteries of cell interaction in humans. ${ }^{68}$ Moreover, understanding the mechanism of penetration of sperm into an egg will also give clues to find out how disease causing cells invade the normal cells. The list is in-exhaustive and many more marine species are on the bench top of biomarine researchers. ${ }^{69}$

\section{CONCLUSION}

Sea contains a big pharmacy for human benefits. Seafood once regarded as a dinner specialty is now getting increased respect among the medical scientists for medicines and future therapies. Marine natural products bio-prospecting has no doubt yielded a considerable number of drug candidates. Most of these molecules are still in pre-clinical or early clinical development but some are already in the market such as cytarabine and ET 743 (Yondelis ${ }^{\mathrm{TM}}$ ) as anticancer drugs, vidarabine as antiviral agent and ziconotide (Prialt $\AA$ ) for management of severe chronic pain. Hundreds of compounds exhibiting strong activities against a variety of infections (e.g. HIV, malaria, staphylococcal and fungal infections), carcinomas including solid human tumors and other disorders (e.g. asthma, atherosclerosis, epilepsy, osteoarthritis and inflammation) have been isolated. Some of these are in the advanced stages of new drugs development .The dozen of molecules have reached the stage of phase I and II of clinical evaluation. The need of the time is to fully identify the genes that produce the desired bioactive compounds with medicinal properties and to transfer those genes to the microorganisms such as Escherichia coli that are easy to culture in the lab. This is must to preserve the marine biota so that it may not get extinct by continuous harvesting from the sea for medical pursuits.

\section{Funding: No funding sources Conflict of interest: None declared \\ Ethical approval: Not required}

\section{REFERENCES}

1. Dias DA, Urban S, Roessner U. A historical overview of natural products in drug discovery. Metabolites. 2012;(2):303-6.

2. Malve H. Exploring the ocean for new drug developments: marine pharmacology. J Pharm Bioallied Sci. 2016;8(2):83-91.
3. Carney JR, Yoshida WY, Kiheisterones SPJ. New cytotoxic steroids from a Maui sponge. J Org Chem. 1992;57(24):6637-40.

4. Zheng LH, Wang YJ, Sheng J, Wang F, Zheng Y, Lin XK, et al. Antitumor peptides from marine organisms. Mar Drug. 2011;9(10):1840-59.

5. Calcabrini C, Catanzaro E, Bishayee A, Turrini E, Fimognari C. Marine sponge natural products with anticancer potential: an updated review. Mar Drugs. 2017; 15(10):310.

6. Spira AI, Iannotti NO, Neubauer M, Ronald NG, Yanagihara H. A phase II study of eribulin mesylate (E7389) in patients with advanced previously treated non-small-cell lung cancer. Clin Lung Cancer. 2012;13(1):31-8.

7. Jain S, Cigler T. Eribulin mesylate in the treatment of metastatic breast cancer. Biologics. 2012;6:21-9.

8. Bai R, Nguyen TL, Burnett JC, Atasoylu O, Munro MHG, Pettit GR, et al. Interactions of Halichondrin B and Eribulin with Tubulin. J Chem Informat Model. 2011;51(6):1393-404.

9. Smith AB, Freeze BS. Discodermolide: total synthesis, construction of novel analogues, and biological evaluation. Tetrahedron. 2007;64(2):26198.

10. Souza MVND. Discodermolid: a marine natural product against cancer. Scientif World J. 2004;4:41536.

11. Murti Y, Agrawal T. Marine derived pharmaceuticals Development of natural health products from marine biodiversity. Int $\mathrm{J}$ Chem Tech Research. 2010;2(4):2198-217.

12. Newman DJ, Cragg GM. Marine natural products and related compounds in clinical and advanced preclinical trials. J Nat Prod. 2004;67(8):1216-38.

13. Huang RM, Chen YN, Zeng Z, Gao CH, Su X, Peng Y. Marine nucleosides: structure, bioactivity, synthesis and biosynthesis. Mar Drugs. 2014;12(12):5817-38.

14. Schwartsmann G, Rocha ABD, Jimeno J, Berlink RGS. Marine organisms as a source of new anticancer agents. Lancet Oncol. 2001;2(4):221-5.

15. Moraes FC, Muricy G. Taxonomy of Plakortis and Plakinastrella (Demospongiae: Plakinidae) from oceanic islands off north-eastern Brazil, with description of three new species. J Mar Biol Assoc U K. 2003:385-97.

16. Halim H, Chunhacha P, Suwanborirux K, Chanvorachote P. Anticancer and antimetastatic activities of Renieramycin M, A marine tetra hydroisoquinoline alkaloid, in human non-small cell lung cancer cells. Anticancer Res. 2011;31(1):193201.

17. Tommonaro G, Iodice C, AbdEl-Hady FK, Guerriero G, Pejin B. The Mediterranean sponge Dysidea avara as a 40 year inspiration of marine natural product chemists. J Biodivers Endanger Species. 2015;1:1.

18. Amade $\mathrm{P}$, Charroin C, Baby C, Vacelet J. Antimicrobial activities of marine sponges from the Mediterranean Sea. Marine Biol. 1987;94:271-5. 
19. Ridley CP, Faulkner DJ, Haygood MG. Investigation of Oscillatoria spongeliae-dominated bacterial communities in four Dictyoceratid Sponges. Appl Environ Microbiol. 2005;71(11):7366-75.

20. Ebada SS, Proksh P. The Chemistry of Marine Sponges. Handbook of Marine Natural Products. Switzerland: Springer Science; 2012: 191-293.

21. Tiwari K, Gupta RK. Rare actinomycetes: a potential storehouse for novel antibiotics. Critic Rev Biotechnol. 2012;32(2):108-32.

22. Jensen PR, Moore BS, Fenical W. The marine Actinomycete genus Salinispora: a model organism for secondary metabolite discovery. Nat Prod Rep. 2015;32(5):738-51.

23. Macherla VR, Mitchell SS, Manam RR, Reed KA, Chao TH, Nicholson B, et al. Structure-activity relationship studies of salinosporamide A (NPI-0052), a novel marine derived proteasome inhibitor. J Med Chem. 2005;48(11):3684-7.

24. Jayaprakashvel M. Therapeutically active biomolecules from marine actinomycetes. J Mod Biotechnol. 2012;1(1):1-7.

25. Popov AM, Stekhova SI, Utkina NK, Rebachuk NM. Antimicrobial and cytotoxic activity of sesquiterpenequinones and brominated diphenyl ethers isolated from marine sponges. Pharm Chem. 1999;33:15-6.

26. Gennari C, Castoldi D, Sharon O. Natural products with taxol-like anti-tumor activity: synthetic approaches to eleutherobin and dictyostatin. Pure Applied Chem. 2007;79(2):173-80,

27. Ehrlich H, Etnoyer P, Litvinov SD, Olennikova MM, Domaschke H, Hanke T, et al. Biomaterial structure in deep-sea bamboo coral (Anthozoa: Gorgonacea: Isididae): perspectives for the development of bone implants and templates for tissue engineering. Materialwissenschaft und Werkstofftechnik. 2006;37(6):552-7.

28. Louisia S, Stromboni M, Meunier A, Sedel L, Petite H. Coral grafting supplemented with bone marrow. J Bone Joint Surg. 1999;81(4):719-24.

29. Grado GFD, Keller L, Idoux-Gillet Y, Wagner Q, Musset AM, Benkirane-Jessel N, et al. Bone substitutes: a review of their characteristics, clinical use, and perspectives for large bone defects management. J Tissue Eng. 2018;9:2041731418776819.

30. Ben-Nissan B. Discovery and development of marine biomaterials. In: Kim S, eds. Functional Marine Biomaterials. Cambridge, United Kingdon: Woodhead Publishing; 2015: 3-32.

31. Look SA, Fenical W, Jacobs RS, Clardy J. The pseudopterosins: Anti-inflammatory and analgesic natural products from the sea whip Pseudopterogorgia elisabethae. Proc Nati Acad Sci U S A. 1986;83:623840

32. Cho J, Kim Y. Sharks: a potential source of antiangiogenic factors and tumor treatments. Mar Biotechnol. 2002;4:521-5.
33. Lu C, Lee JJ, Komaki R, Herbst RS, Feng L, Evans WK, et al. With or without AE-941 in stage III nonsmall cell lung cancer: a randomized phase III trial. J Natl Cancer Inst. 2010;102(12):859-65.

34. D'Incalci M, Jimeno J. Preclinical and clinical results with the natural marine product ET-743. Expert Opin Investig. 2003;2(11):1843-53.

35. Schmitt T, Keller E, Dietrich S, Wuchter P, Ho AD, Egerer G. Trabectedin for metastatic soft tissue sarcoma: a retrospective single center analysis. Mar Drugs. 2010;8(10):2647-58.

36. Erba E, Bergamaschi D, Ronzoni S, Faircloth GT, Bassano L, Damia G. Ecteinascidin-743 (ET-743), a natural marine compound, with a unique mechanism of action. Euro J Cancer. 2001;37(1):97-105.

37. Palanisamy SK, Rajendran NM, Marino A. Natural products diversity of marine Ascidians (Tunicates; Ascidiaacea) and successful drugs in clinical developments. Nat Prod Bioprospect. 2017;7(1);1-11.

38. Prashanth JR, Dutertre S, Lewis RJ. Pharmacology of predatory and defensive venom peptides in cone snails. J Molecul Biosyst. 2017;12:2453-62.

39. Safavi-Hemami H, Brogan SE, Olivera BM. Pain therapeutics from cone snail venoms: from ziconotide to novel non-opioid pathways. J Proteomics. 2019;190:12-20.

40. Detert JA, Adams EL, Lescher JD, Lyons JA, Moyer JR. Pretreatment with apoaequorin protects hippocampal CA1 neurons from oxygen-glucose deprivation. PLoS One. 2013;8(11):79002.

41. Lee Y, Phat C, Hong SC. Structural diversity of marine cyclic peptides and their molecular mechanisms for anticancer, antibacterial, antifungal, and other clinical applications. Peptides. 2017;95:94105.

42. Watters DJ. Ascidian toxins with potential for drug development. Mar Drugs. 2018;16(5):162.

43. Benchamas G, Huang G, Huang S, Huang $H$. Preparation and biological activities of chitosan oligosaccharides. Trends Food Sci Technol J. 2021;107:38-44.

44. Li CP, Prescott B, Eddy B, Caldes G, Green WR, Martino EC, et al. Antiviral activity of paolins from clams. Annals New York Aca Sci. 1965;130(1):37482

45. Li CP, Prescott B, Martino C, Liu OC. Antineoplastic activity of Clam Liver extract. Nature. 1968;219(5159);1163-4.

46. Waibel KH, Brian H, Moore M, Bonnie W, Gomez R. Safety of chitosan bandages in shellfish allergic patients. Mill Med. 2011;176(10):1153-6.

47. Wargasetia TL, Wido D. Mechanisms of cancer cell killing by sea cucumber-derived compounds. Invest New Drugs. 2017;35(6):820-6.

48. PereiraPint E, Rodrigue SM, Gouveia N, Timóteo V, Costa PR. Tetrodotoxin and saxitoxin in two native species of puffer fish, Sphoeroides marmoratus and Lagocephalus lagocephalus from NE Atlantic Ocean (Madeira Island, Portugal). Mar Environment Res. 2019;15:1047. 
49. Cusick KD, Sayler GR. An overview on the marine neurotoxin, saxitoxin: genetics, molecular targets, methods of detection and ecological functions. Mar Drugs. 2013;11(4):991-1018.

50. Puilingi CG, Kudo Y, Cho Y, Konoki, Yamashita MY. Tetrodotoxin and its analogues in the pufferfish Arothron hispidus and A. nigropunctatus from the Solomon Islands: a comparison of their toxin profiles with the same species from Okinawa, Japan. Toxins (Basel). 2015;7(9):3436-54.

51. Liu J, Li XW, Guo YW. Recent advances in the isolation, synthesis and biological activity of marine guanidine alkaloids. Marine Drugs. 2017;15(10):324.

52. Klein-Júnior LC, Santin JR, Niero R, deAndrade SF, Filho VC. The therapeutic lead potential of metabolites obtained from natural sources for the treatment of peptic ulcer. Phytochem Rev. 2011;11:567-616.

53. Martínez-Núñez MA, López VELY. Nonribosomal peptides synthetases and their applications in industry. Sustain Chem Process. 2016;4:13

54. Riyanti R, Widada J, Radjasa OK. Isolation and screening of antimicrobial producing-actinomycetes symbionts in Nudibranch. Indones $\mathbf{J}$ Biotechnol. 2009;14(1).

55. Thomas ATR, Kavlekar DP, LokaBharathi PA. Marine drugs from sponge-microbe association-a review. Mar Drugs. 2010;8(4):1417-68.

56. Dyshlovoy SA, Kudryashova EK, Kaune M, Makarieva TN, Shubina LK, Busenbender T, et al. Urupocidin C: a new marine guanidine alkaloid which selectively kills prostate cancer cells via mitochondria targeting. Scientif Rep. 2020;10(9764):66428-95.

57. Dyshlovoy SA, Tabakmakher KM, Hauschild, J, Shchekaleva RK, Otte K, Guzii AG. Guanidine alkaloids from the marine sponge Monanchora pulchra show cytotoxic properties and prevent EGF-induced neoplastic transformation in vitro. Mar Drugs. 2016;14(7):133.

58. Dyshlovoy SA, Kudryashova EK, Kaune M, Tatyana M, Makarieva N, Shubina LK, et al. Urupocidin C: a new marine guanidine alkaloid which selectively kills prostate cancer cells via mitochondria targeting. Sci Res. 2020;10(1):9764.

59. Cheung FRC, Ng TB, Wong JH, Chen Y, Chan W. Marine natural products with anti-inflammatory activity. Appl Microbiol Biotechnol. 2016;100(4):1645-66.
60. Welch L. Sea life benefits us in more ways than you imagine. Alaska J Commerce. 2005 Nov 26. Available at: https://www.alaskajournal.com. Accessed on $20^{\text {th }}$ March 2021.

61. Shikov AN, Pozharitskaya ON, Krishtopina AS. Naphthoquinone pigments from sea urchins: chemistry and pharmacology. Phytochem Rev. 2018;17(2):509-34.

62. Karthigayan S, Balasubashini MS, Sengottuvelan M, Balasubramanian T. Anticancer principles from salivary gland extract of Octopus ageina. Int $\mathrm{J}$ Cancer Res. 2006;2(3):242-52.

63. Jinson ST, Liebich J, Senft SL, Mathger LY. Retinal specializations and visual ecology in an animal with an extremely elaborate pupil shape: the little skate Leucoraja (Raja) erinacea Mitchell 1825. J Comparative Neurol. 2018;526(12):1962-77.

64. Arkansas Democrat Gazette. Fact sheet: New fish discoveries could lead to medical breakthroughs, 2019. Available at: https://www.arkansasonline.com/news/2019/apr/21/n ew-fish-discoveries-could-lead-medicalbreakthrou/?threerivers. Accessed on 14 April 2021.

65. Rome LC. Design and structures of superfast muscles, new insights to the physiology of skeletal muscles. Ann Rev Physiol. 2006;68:193-221.

66. Szatkowski ML, Westfall MV, Gomez CA, Wahr PA, Daniel E, DelloRusso MC. In vivo acceleration of heart relaxation performance by parvalbumin gene delivery. J Clin Invest. 2001;107(2):191-8.

67. Voskoboynik A, Weissman IL. Botryllus schlosseri, an emerging model for the study of aging, stem cells, and mechanisms of regeneration. Invertebr Reprod Dev. 2015;59(1):33-8.

68. Metz EC, Kane RE, Yanagimachi H, Parlumbi SR. Fertilization between closely related sea urchins is blocked by incompatibilities during sperm-egg attachment and early stages of fusion. Biol Bulletin. 1994;187(1):23-34.

69. Carlos J. Marine natural products in medicinal chemistry. Med Chem Lett. 2018;9(10):959-61.

Cite this article as: Goel R, Mahendru B, Saini T. Marine natural products: the new generation of pharmacotherapeutics. Int J Basic Clin Pharmacol 2021;10:876-85. 